PROCESSING OF MARC TAPES FOR COOPERATIVE USE

Kenneth John BIERMAN: Data Processing Coordinator, Oklahoma Department of Libraries, and Betty Jean BLUE: Programmer, Information and Management Services Division, State Board of Public Affairs, Oklahoma City, Oklahoma

A centralized data base of MARC II records distributed by the Library of Congress is discussed. The data base is operated by the Oklahoma Department of Libraries and is available to any library that can make use of it. The history, creation, operation, uses, advantages, disadvantages, cost and future plans of the data base are included, as well as flowcharts (both system and detail) and sample outputs.

\title{
BACKGROUND INFORMATION
}

Early in 1966, college, university and public librarians in Oklahoma began meeting irregularly to discuss library automation. The incentive for such meetings was clear - libraries in Oklahoma could not justify the financial expenditure necessary to "go their own road" in library automation. Secondarily, they realized that at some time in the future, cooperative automation projects begun now would pay big dividends.

With the coming of Library of Congress MARC II distribution service in April 1969, interest in library automation once again came to the forefront in Oklahoma library circles. After several general meetings, primar- 
ily to find out what others were doing, planned to do, had done, or had failed to do, a MARC planning meeting was called by the Oklahoma Department of Libraries. Representatives (both administrative and technical) of the three colleges, two public library systems, and two universities that were most likely to be doing anything with MARC in the immediate future, were invited. The feeling expressed at the meeting was that if economic use of MARC were to be made in Oklahoma, there would have to be cooperative effort so that MARC data could be used at the least total cost. At the same time, libraries had planned different uses of MARC; therefore, allowance for local autonomy and creative use of MARC was important.

Since libraries were planning varying applications of MARC, it was decided that the best place to begin a cooperative effort was in the centralized maintenance of a MARC data base. Four libraries in Oklahoma had placed subscriptions with the Library of Congress for the MARC II tapes when they became available - one public library, one college library, one university library, and the Department of Libraries. The cost of maintaining four complete data bases would be large compared to the cost of maintaining one complete data base in the state for everyone's use. The money saved could then be used for utilization of MARC records rather than for housekeeping maintenance of MARC records. Mr. Ralph Funk, Director of the Oklahoma Department of Libraries, committed the Department to obtaining and maintaining a complete file of all cataloging information sent out by the Library of Congress in MARC II machine readable format (both current and, when available, retrospective) which would always be available on demand (either in part or in whole) to any library in the State.

This report describes the cooperative system developed by the Department of Libraries to maintain and make available MARC II records to any library in the State that has the computer equipment to make use of them. Unlike NELINET (1) and the Washington State System (2), which are processing MARC tapes to produce final hard-copy products for the cooperating libraries, the Oklahoma system provides the machine readable MARC records (not final products) a library needs; then that library can process these records in any way it wishes on its own equipment. None of the MARC I participants was primarily concerned with the central distribution of selected machine readable records (3). Possible future state-wide cooperative ventures with MARC (including useful products) are also discussed.

\section{OVERVIEW OF THE SYSTEM}

The system can be thought of as two sub-systems: 1) Merging and maintaining a MARC master file of all records sent out by the Library of Congress in MARC II format, and 2) retrieving-i. e., withdrawing- 
selected records by LC card number from the MARC master file for specific libraries on demand.

The maintenance sub-system has four distinct programs: 1) ODL- $\emptyset 1$, which merges MARC tapes; 2) ODL- $\emptyset 3$, which drops or transfers to another tape any record or combination of records on a given MARC tape; 3) ODL- 94 , which prints a MARC tape in upper-case EBCDIC; 4) ODL- $\emptyset 6$, which prints the LC numbers (300/page) from any given MARC tape.

The retrieval sub-system has one program, ODL- $\emptyset 5$, which selects and copies specified LC card number records from the MARC master file to a blank magnetic tape to be sent to the requesting library for its use.

\section{THE MAINTENANCE SUB-SYSTEM}

The programs discussed in this section are used to merge and maintain the MARC data base (ODL- $\emptyset 1$ and ODL- $\emptyset 3$ ) and produce hard-copy by-products which are of occasional use for various purposes (ODL- $\emptyset 4$ and ODL- $(6)$. System, input and output descriptions are included for each program.

\section{Record Merge Program}

This program takes tapes in MARC format and code and merges them in LC card number sequence. During processing, messages print if any unusual conditions occur, such as a new record with status other than " $\mathrm{n}$ " (new), a matched record with a code other than " $\mathrm{c}$ " (corrected), or "d" (deleted), etc. The messages also indicate the action taken. In general, any new record is merged onto the file regardless of code, a match with code " $\mathrm{d}$ " causes deletion, and a match with code " $c$ " (and any other match) results in replacement by the new record. This occasionally causes "invalid" codes to be merged onto the file, but this approach was taken for three major reasons, one being that it is usually easier, in cases of error, to remove a bad record from the master than to retrieve it from its source and then merge it onto the master.

Secondly, as files become larger, it is feasible to make minor merges of a few tapes, then merge the result onto the actual master. During the minor merge, many apparently new records with codes " $\mathrm{c}$ " and " $\mathrm{d}$ " will appear, but as the final merge is made, appropriate action is taken.

Thirdly, a library obtaining MARC records from the Department of Libraries may also want to use the ODL- $\emptyset 1$ merge for its own internal use. Some of the records requested by the local library may have been corrected at some time and are therefore coded "c". Although new to the individual library, these are coded " $\mathrm{c}$ ", but are perfectly valid records from that library's point of view. Since the ODL- $\emptyset 1$ merge always merges a new record onto the file regardless of the code, this program can be used by the individual library without modification. 
Inputs are 1) a MARC master (a tape in MARC format and code containing all records merged to date), which is in LC card number sequence; and 2) MARC "items" (a tape(s) in MARC format and code containing the new records to be merged.) Processing halts if this tape(s) is out of sequence.

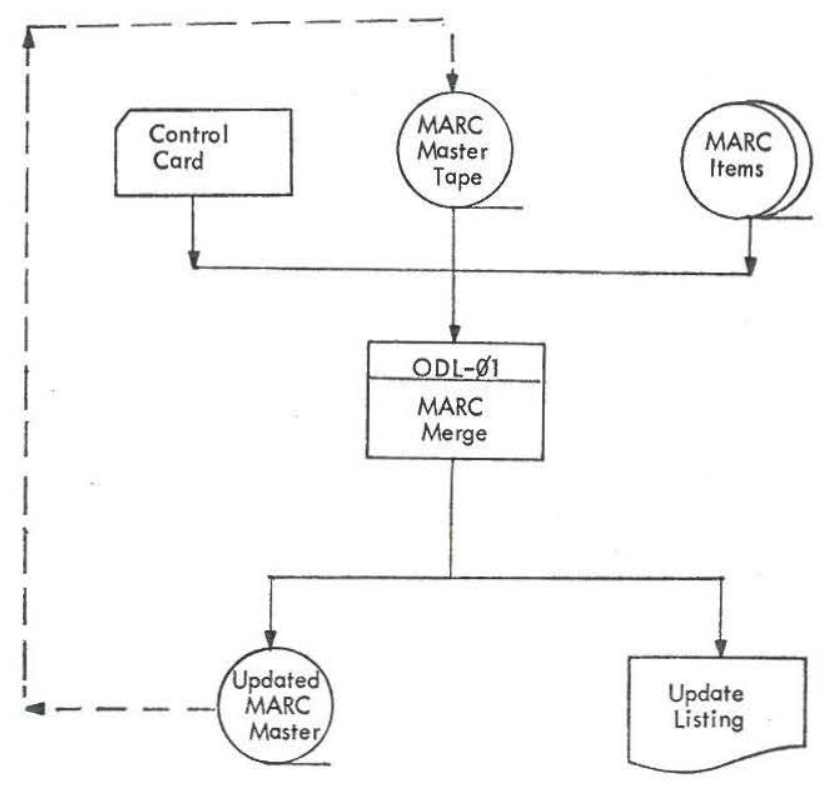

Fig. 1. Record Merge Program System Flowchart.

Outputs are 1) a MARC master, which is a tape containing records from all inputs, with appropriate corrections and deletions made; and 2) a merge listing, which contains notices of all corrections and deletions and notices of all unusual conditions. If desired, this listing can be expanded to print certain desirable information from all records merged and thus can be used as a valuable reference and check list. It will contain the LC card number, with prefixes and suffixes, and status code, and will indicate if a match was found on the master tape and the action taken.

Figure 1 explains the overall flow of the program. Figure 2 gives the program details as of September 1969. 


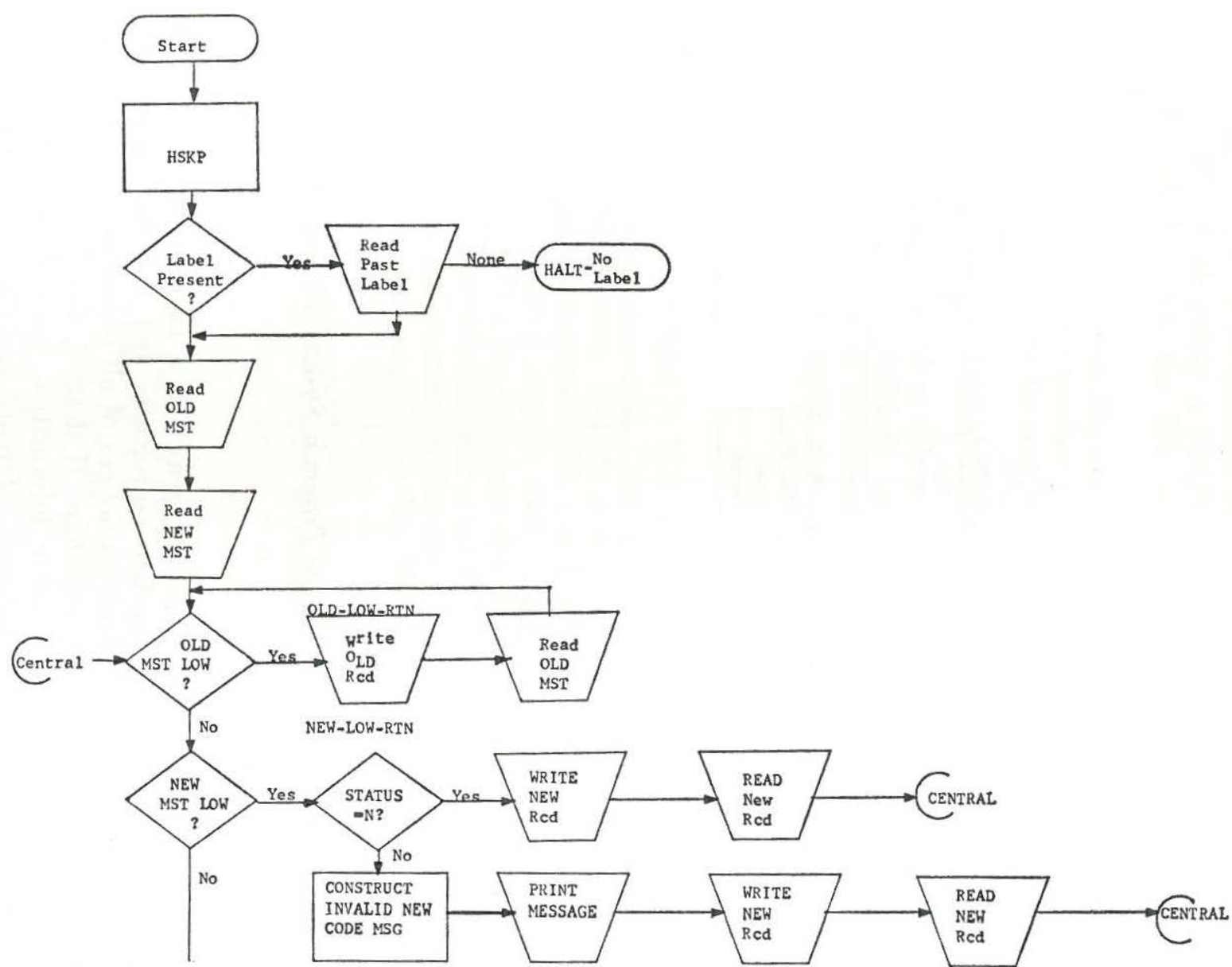

Fig. 2. Record Merge Program Detail Flowchart. 


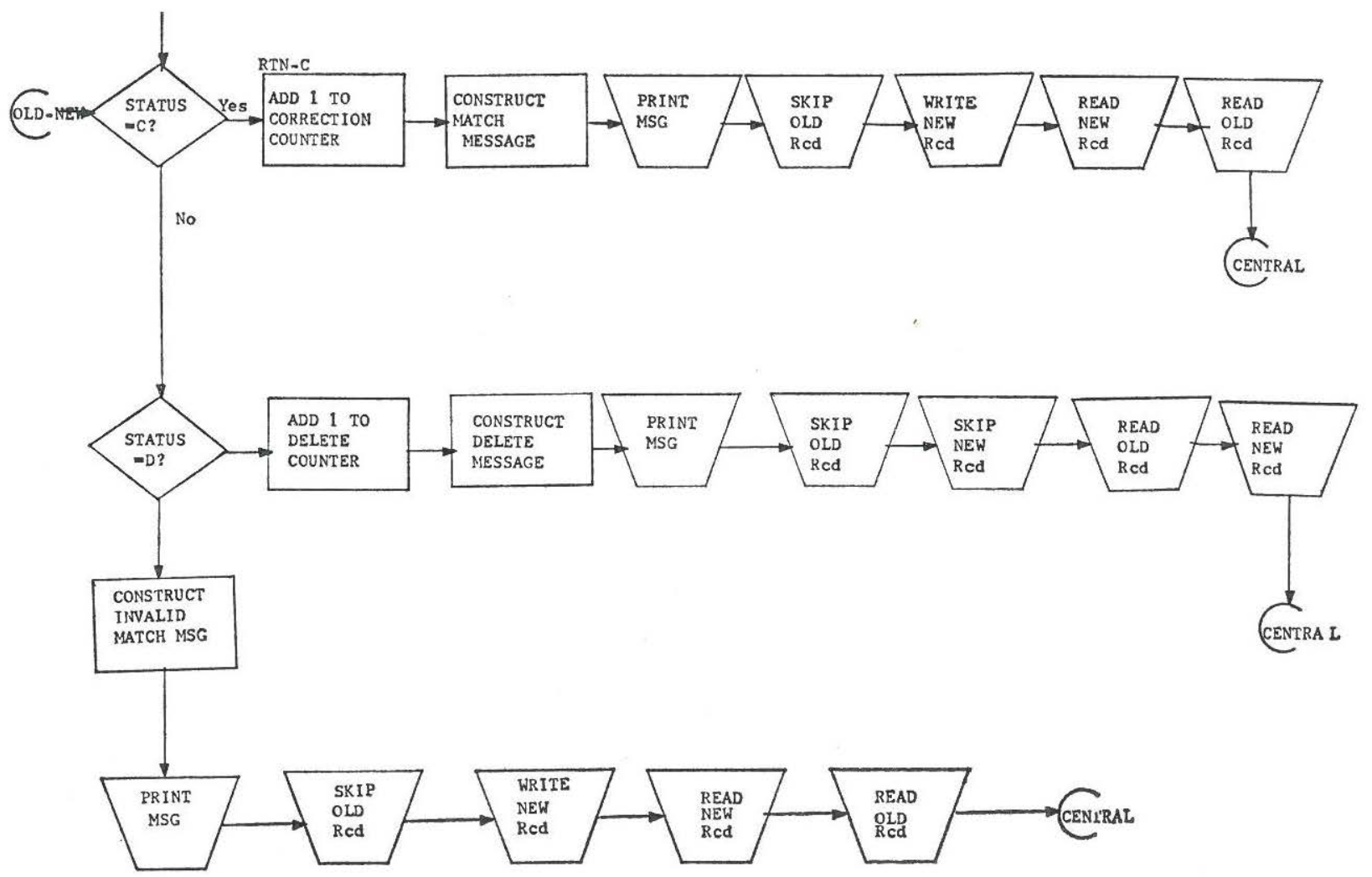

Fig. 2 continued. 

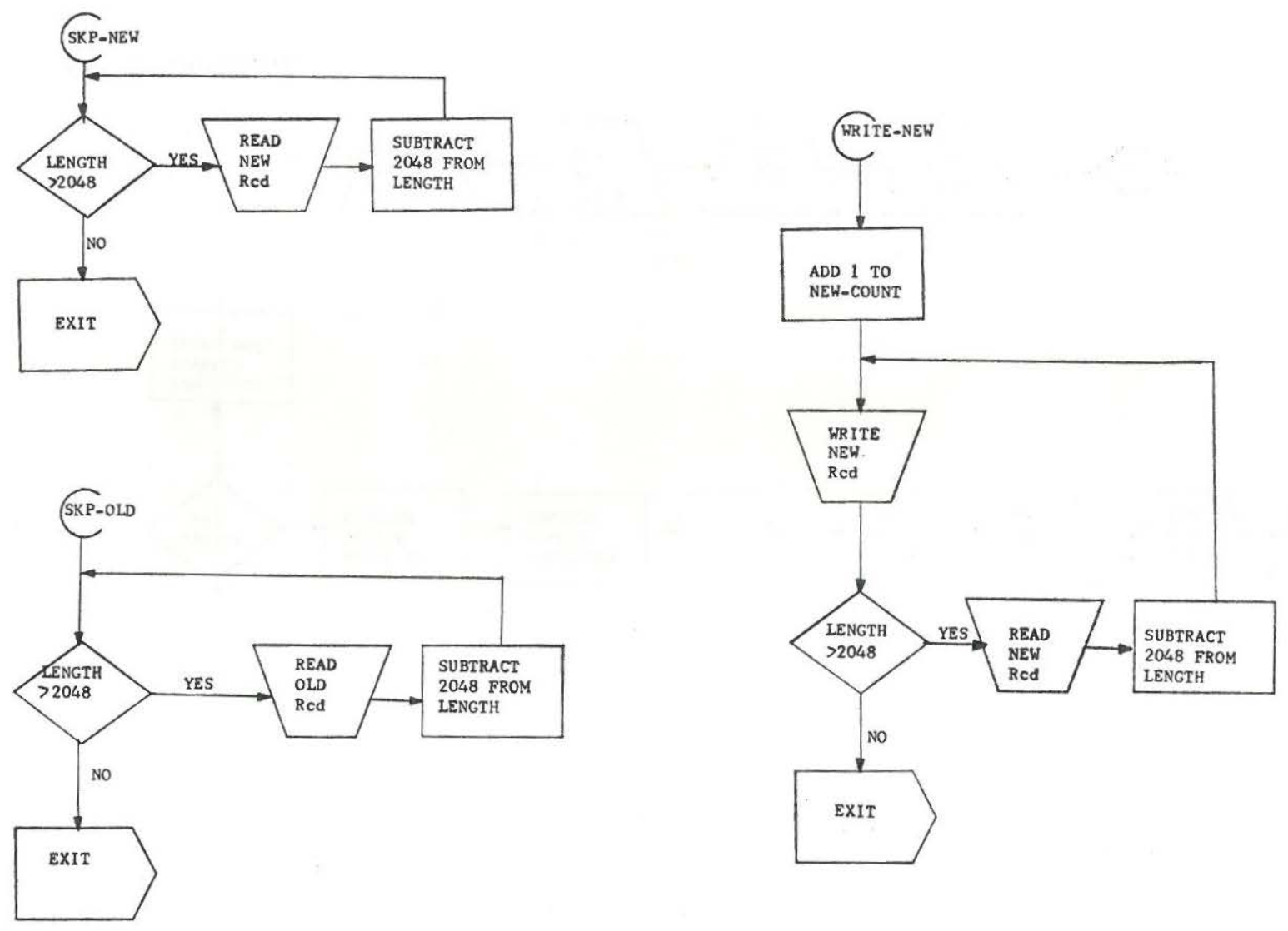

Fig. 2 continued. 

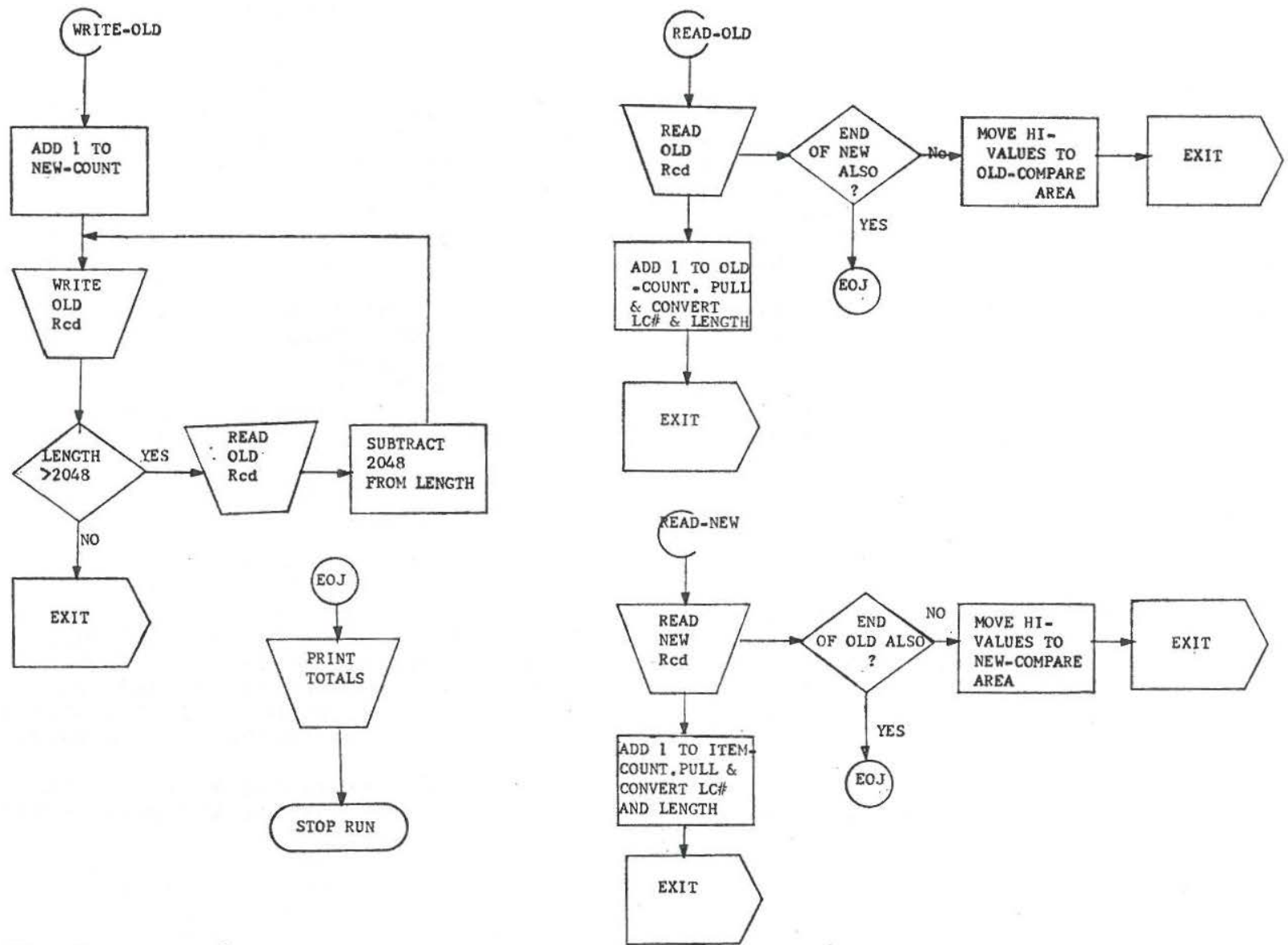

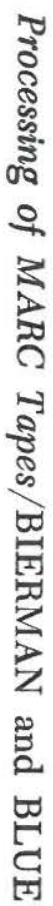

Fig. 2 continued. 

0370030530000330034250000890037550400290046465000320049365000240052570000460054970000460059571000400 $\begin{array}{llll}0641 \varepsilon & 67026007 & 690324 \$ 1968 \text { MOUA B } 10100 \text { ENGO \&O \$ARC } 847 \$ 8 . A 671966 \varepsilon \quad \$ 4616.3 / 62 / 0755820\end{array}$ \$AAPPLIED SEMINAR ON THE LABORATORY DIAGNOSIS OF LIVER DISEASES, \$CWASHINGTON, D.C.,\$DI966.\&I \$ALABOR AIORY DIAGNOSIS OF LIVER DISEASES. SCCOMPILED AND EDITED BY F. WILLIAM SUNOERMAN AND F. WILLIAM SUNDE RMAN, JR॰ \&O \$AST. LOUIS,\$BW. H. GREEN\$C $\$ C 1968 * \varepsilon$ \$AXIII, 542 P.\$BILLUS.\$C 27 CM. E \$AHELD UNDER THE A USPICFS DF THE ASSOCIATION OF CLINICAL SCIENTISTS, NOV. 10-13, 1966.E \$AINCLUDES BIBLIOGRAPHIES.EOO \$AL IVER \$XOISEASES\$XDIAGNOSIS.\&00\$AMEDICINE, CLINICAL.\&IO\$ASUNDERMAN, FREDERICK WILLIAM, \$DI898-\$EED. \& 10 \$ASUNDERMAN, FREDERICK WILLIAM,\$D1931-\$EED.\&20\$AASSOCIATION OF CLINICAL SCIENTISTS.

OOT78NAM 2200169

0010013000000080041000130500019000540820010000731000037000832450295001202600 $04600415300002600461500003800487500002800525652002800553740002800581 \varepsilon \quad 67028617$ \& $690324 R 19681846 M D U$ C C 00000 FNGO \&O \$AF93\$B.H65 1968\& \$A929.3\&10\$AHINMAN, ROYAL RALPH, \$D1785=1868. \&1 \$AA CATAL OGUF OF THE NAMES OF THE FIRST PURITAN SETTLERS OF THE COLONY OF CONNECTICUT, \$BWITH THE TIME OF THEI R ARRIVAL IN THE COLONY, AND THEIR STANDING IN SOCIETY, TOGETHER WITH THFIR PLACE OF RESIDENCE, AS F AR AS CAN BE DISCOVERED BY THE RECORDS. \$CCOLLECTED FROM THE STATE AND TOWN RECORDS. EO \$ABALIIMORE, \$B GENEALOGICAL PUB. CO.\$C1968.\& \$A336 P.\$BPORT.\$C23 CM.E \$AON SPINE* FIRST PURITAN SETTLERS.\& \$ARE PRINT OF THE 1846 ED.\&OO\$ACONNECTICUT\$XGENEALOGY.\&01\$AFIRST PURITAN SETTLERS.*

O0896NAM 2200193

0010013000000080041000130500017000540820010000711000021000812450128001022600 $05000230300003200280490005800312500013300370504003100503650003100534710006100565810007700626 \varepsilon \quad 6703$ 0030 \&690324S1968 NYUA B 00010 ENGO \&0 \$ARA395.A3\$BU4E \$A362.1E10\$AULLMANN, JOHN E.E1 \$AT HE APPLICATION OF MANAGEMENT SCIENCE TO THF EVALUATION AND DESIGN UF REGIONAL HFALTH SERVICES, \$CEDIT ED BY JOHN E. ULLMANN. EO \$A\#HEMPSTEAU, N.Y.,\$BHOFSTRA UNIVERSITY\#\$C1968.\& \$AIII, 346 P.\$BILLUS.\$C28 CM. $\& 1$ \$AHOFSTRA UNIVERSITY YEARBOOK DF BUSINESS, SER. 5, V. $2 \varepsilon$ \$A* THIS* REPORT RESULTS FROM THE C ONIINUING SERIES DF M.B.A. SEMINARS CONDUCTED BY THE SCHODL DF BUSINESS OF HOFSIRA UNIVERSITY. * $E$ SA BIBLIOGRAPHICAL FROTNOTES. EOO\$ACOMMUNITY HEALTH SERVICES. \& 2O\$AHOFSTRA UNIVERSITY, HEMPSTEAD, N.Y. \$BS CHOLL OF BUSINESS. E2 \$AHOFSTRA UNIVERSITY, HEMPSTEAD, N.Y.\$TYEARBUOK OF BUSINFSS, \$VSER. 5, V. 2*

00844NAM 2200217 0010013000000080041000130410011000540500018000650820014000831000027000972450 0940012426000580021830000490027635000100032549000730033550400810040865000260048965000330051584000270 $0548840005200575 \varepsilon \quad 67031114$ \&690328\$1968 NJUA B O0100 ENGO E1 \$AENGFRFE0 \$AN7832\$B.G6613\&

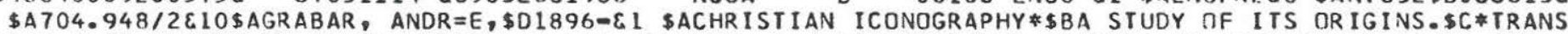
LATED FROM FRENCH BY TERRY GRABAR•\&O \$APRINCETON, N.J.*\$BPRINCETON UNIVERSITY PRESS\$C*CI968*\& \$AL. 174, \$203* P.\$BILLUS. (PART COL.)\$C27 CM.\& \$AI5.00\&1 \$ABOLLINGEN SERIES, 35. THE A. W. MELLON LECTU RES IN THE FINE ARTS, 10\& \$ABIBLIOGRAPHY*P. 149-158 (20 GROUP) *ILLUSTRATIONS* P. *1*-*203* (3D G ROUP) $\& 00 \$ A A R T$, EARLY CHRISTIAN. EOO\$ACHRISTIAN ART AND SYMBCLISM•E \$ABOLLINGFN SERIES, \$V $35 . \&$ \$ATHE A. W. MELLON LECTURES IN THE FINE ARTS, \$VIO*

Fig. 3. Print Record Program Output. 


\section{Drop and Transfer Records Program}

This is a utility program that enables any number of LC card numbers to be entered on cards, with the option in each case of dropping the record entirely or transferring it to another tape for future action. It has proven useful for removing out-of-sequence records, purging files, etc.

Inputs are two in number: 1) any tape in MARC code and format (sequence is not checked); and 2) detail cards, each of which contains a 12-position LC card number and a code indicating if this MARC record is to be dropped or transferred to another tape. These cards must be in sequence.

There are three outputs: 1) an updated tape containing all MARC records on which no action was taken; 2) transferred tape containing, in sequence, all records transferred; and 3) a listing showing the LC number and the action taken, which is useful for verification of results.

\section{Print Record Program}

This program prints in readable form any tape in MARC code and format. The translation table, which produces a form of upper-case EBCDIC, is the same as that used for other Department of Libraries programs. It is a character-for-character translation, which, for the present, is useful for many and varied applications. Input is any tape in MARC code and format. Output is an upper-case EBCDIC translation of the tape. Figure 3 shows a sample output.

Figure 4 shows how the Oklahoma Department of Libraries is handling the MARC expanded character set with a small printer (IBM 1404-48 characters). Simply stated, the problem is that there are many more characters coded in the MARC ASCII character set than are available on the particular printer that the Department of Libraries is using. (This is a local limitation of the printer that happens to be available; it is not a limitation of computer technology, as printers with expanded character sets are readily available).

In general, rarely used punctuation and special punctuation marks not in the printer's character set print as an "»", the lower-case letters print their upper-case equivalents, and diacriticals and foreign language symbols print as " $="$. This translation table is used for in-house lists (for checking purposes, etc.). For production purposes, a slightly different translation table is used. Characters, particularly punctuation marks, not available on the printer are translated to their closest equivalent or left blank, whichever is more appropriate.

At the Oklahoma Department of Libraries, all translations at this time are internal and do not affect the MARC tapes, which are being left in the original ASCII code. It seemed unreasonable to centrally translate the tapes to EBCDIC until agreement among all the users could be reached as to a mutually useful translation table. 
There is a good possibility that in the near future the Information and Management Services Division will make available an off-line printer with an expanded character set (upper- and lower-case letters, additional punctuation, etc.). If this does happen, then print-outs in an expanded character set would be economically possible.

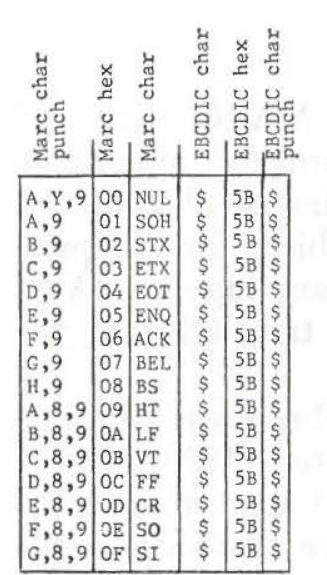

\begin{tabular}{|l|l|l|l|l|l|}
\hline $\mathrm{A}, \mathrm{Q}, 9$ & 10 & $\mathrm{DLE}$ & $\$$ & $5 \mathrm{~B}$ & $\$$ \\
$\mathrm{~J}, 9$ & 11 & $\mathrm{DC} 1$ & $\$$ & $5 \mathrm{~B}$ & $\$$ \\
$\mathrm{~K}, 9$ & 12 & $\mathrm{DC} 2$ & + & $4 \mathrm{E}$ & + \\
$\mathrm{L}, 9$ & 13 & $\mathrm{DC} 3$ & $\$$ & $5 \mathrm{~B}$ & $\$$ \\
$\mathrm{M}, 9$ & 14 & $\mathrm{DC} 4$ & $\$$ & $5 \mathrm{~B}$ & $\$$ \\
$\mathrm{~N}, 9$ & 15 & $\mathrm{NAK}$ & $\$$ & $5 \mathrm{~B}$ & $\$$ \\
0,9 & 16 & $\mathrm{SYN}$ & $\$$ & $5 \mathrm{~B}$ & $\$$ \\
$\mathrm{P}, 9$ & 17 & $\mathrm{ETB}$ & $\$$ & $5 \mathrm{~B}$ & $\$$ \\
$\mathrm{Q}, 9$ & 18 & $\mathrm{CAN}$ & $\$$ & $5 \mathrm{~B}$ & $\$$ \\
$\mathrm{~J}, 8,9$ & 19 & $\mathrm{EM}$ & $\$$ & $5 \mathrm{~B}$ & $\$$ \\
$\mathrm{~K}, 8,9$ & $\mathrm{IA}$ & $\mathrm{SUB}$ & $\$$ & $5 \mathrm{~B}$ & $\$$ \\
$\mathrm{~L}, 8,9$ & $1 \mathrm{~B}$ & $\mathrm{ESC}$ & $\$$ & $5 \mathrm{~B}$ & $\$$ \\
$\mathrm{M}, 8,9$ & $1 \mathrm{C}$ & $\mathrm{FS}$ & $\$$ & $5 \mathrm{~B}$ & $\$$ \\
$\mathrm{~N}, 8,9$ & $1 \mathrm{D}$ & $\mathrm{GS}$ & $*$ & $5 \mathrm{C}$ & $\dot{4}$ \\
$0,8,9$ & $1 \mathrm{E}$ & $\mathrm{RS}$ & $\&$ & $5 \emptyset$ & 8 \\
$\mathrm{P}, 8,9$ & $1 \mathrm{~F}$ & $\mathrm{US}$ & $\$$ & $5 \mathrm{~B}$ & $\$$ \\
\hline
\end{tabular}
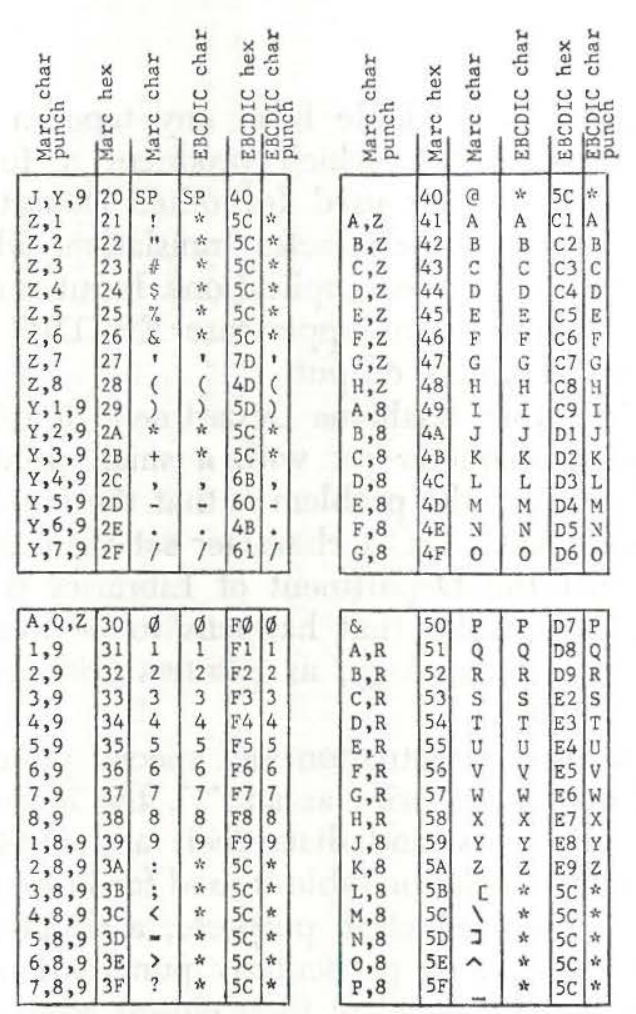

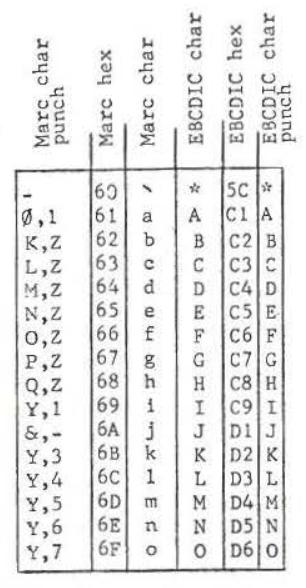

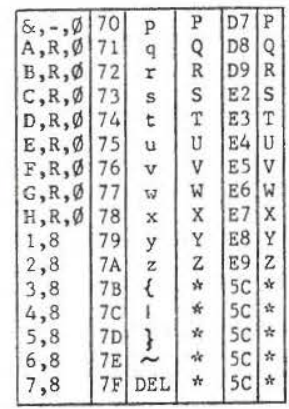

MARC hex $1 \mathrm{C}=$ tepe marc
MARC hex $1 \mathrm{D}=$ end of record
MARC hex $1 \mathrm{E}=$ field terminator
MARC hex $1 \mathrm{~F}=$ delimeter

Fig. 4. Conversion Table. 


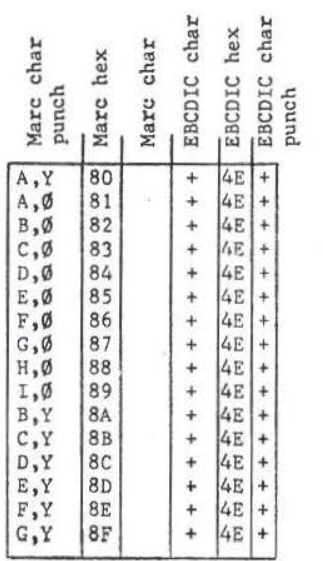

\begin{tabular}{|l|l|l|l|l|l|}
\hline $\mathrm{A}, \mathrm{Q}$ & 90 \\
$\mathrm{~A},-$ & $9 \mathrm{I}$ & + & + & $4 \mathrm{E}$ & + \\
$\mathrm{B},-$ & 92 & $4 \mathrm{E}$ & + \\
$\mathrm{C},-$ & 93 & + & $4 \mathrm{E}$ & + \\
$\mathrm{D},-$ & 94 & + & $4 \mathrm{E}$ & + \\
$\mathrm{E},-$ & 95 & + & $4 \mathrm{E}$ & + \\
$\mathrm{F},-$ & 96 & + & $4 \mathrm{E}$ & + \\
$\mathrm{G},-$ & 97 & + & $4 \mathrm{E}$ & + \\
$\mathrm{H},-$ & 98 & + & $4 \mathrm{E}$ & + \\
$\mathrm{I},-$ & 99 & + & $4 \mathrm{E}$ & + \\
$\mathrm{B}, \mathrm{Q}$ & $9 \mathrm{~A}$ & + & + \\
$\mathrm{C}, \mathrm{Q}$ & $9 \mathrm{~B}$ & + & + \\
$\mathrm{D}, \mathrm{Q}$ & $9 \mathrm{C}$ & + & + \\
$\mathrm{E}, \mathrm{Q}$ & $9 \mathrm{D}$ & + \\
$\mathrm{F}, \mathrm{Q}$ & $9 \mathrm{E}$ & + & + \\
$\mathrm{G}, \mathrm{Q}$ & $9 \mathrm{E}$ & + & + \\
\hline
\end{tabular}

( 1 s $\&, 5,8$

+ is \& $8,6,8$

\& 1 is 12 zone

$\$ 1$ s $-, 3,8$

Fig. 4 continued.
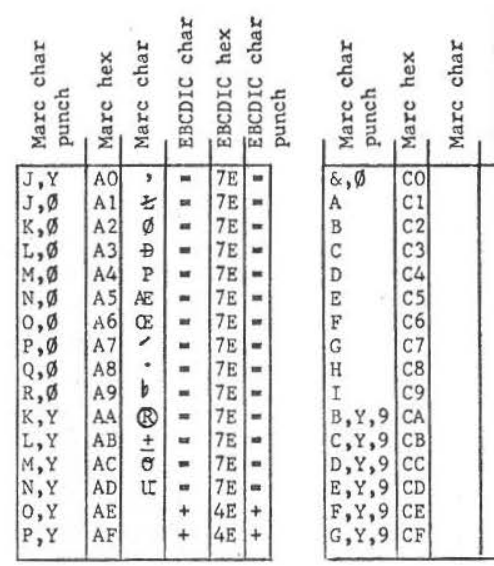

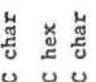

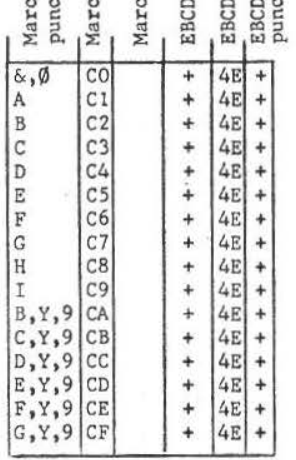

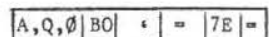

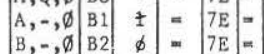

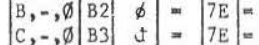
$D,-, \varnothing$ B $p=7 \mathrm{p}=$ $\mathrm{E},-, \emptyset \mathrm{B} 5 \stackrel{\mathrm{P}}{\propto 2}=7 \mathrm{E}=$

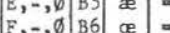

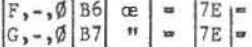
$\mathrm{H},-, \emptyset \mathrm{B} 8+\mathrm{7E}=$ $\begin{array}{lll}\mathrm{I},-, \varnothing & \mathrm{B} 9 & \pm\end{array}$ \begin{tabular}{ll|l|l|}
\hline,,,$- \emptyset$ & $B 9$ & $£$ \\
$B, Q, \emptyset$ & $B A$ & $\partial$ \\
\hline
\end{tabular} $\mathrm{C}, Q, \emptyset \mathrm{BB}+4 \mathrm{E}+$ $\mathrm{D}, \mathrm{Q}, \emptyset \mathrm{BC}$ $\sigma=7 \mathrm{E}-$ $E, Q, \varnothing \quad B D \cup$ $F, Q, \emptyset$ BE $G, Q, \varnothing \mid B F$

\begin{tabular}{|c|c|c|}
\hline,$- \emptyset$ & |DO| & $+|4 E|+$ \\
\hline $\mathrm{J}$ & D1 & $+4 E+$ \\
\hline K & D2 & $+|4 E|+$ \\
\hline 4 & D3 & $+|4 \mathrm{E}|+$ \\
\hline$M$ & D4 & $+|4 \mathrm{E}|+$ \\
\hline N & D5 & $+4 \mathrm{E}$ \\
\hline D & D6 & $+4 \mathrm{E} \mid$ \\
\hline D & D7 & $+|4 \mathrm{E}|+$ \\
\hline D & D8 & $+|4 \mathrm{E}|+$ \\
\hline & D9 & $+|4 E|+$ \\
\hline$B, Q, 9$ & $\mathrm{DA}$ & $+|4 \mathrm{E}|+$ \\
\hline$C, Q, 9$ & DB & $+4 \mathrm{E}+$ \\
\hline$D, Q, 9$ & DC & $+4 \mathrm{E} \mid+$ \\
\hline$E, Q, 9$ & DD & $+4 \mathrm{E}+$ \\
\hline \begin{tabular}{ll|l}
$F, Q, 9$ & $D$ \\
$G, Q, 9$
\end{tabular} & $\mid \begin{array}{l}\mathrm{DE} \\
\mathrm{DF}\end{array}$ & $\begin{array}{r}4 \mathrm{E} \\
+4 \mathrm{E}\end{array}$ \\
\hline
\end{tabular}

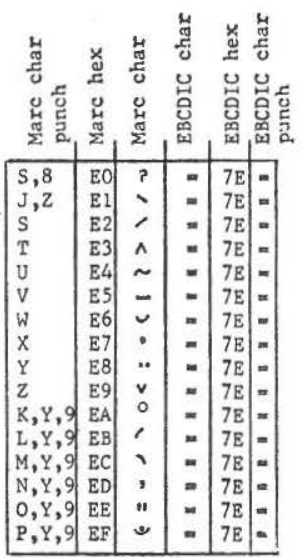

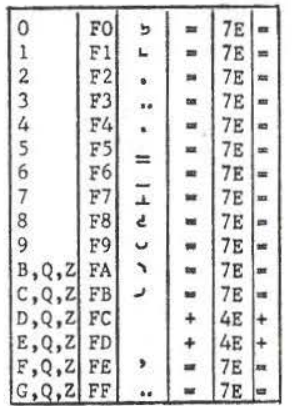

\section{Print Card Numbers Program}

This program prints all LC card numbers on any tape in MARC code and format. Numbers are 12 positions in length and print $300 /$ page in translated form. Occasionally, a cumulative list of LC card numbers on the master tape is produced as a reference tool. Its input is any tape in MARC code and format, its output a printed listing of all Library of Congress numbers on the tape (Figure 5). A record count will appear at the end of the listing.

Figure 6, the detail flowchart for this program, appears on the following pages. 
LC NUMBER LISTING

62022062
63011276
63022268
63064323
63065066
64017102
64023532
64062037
64062399
64062867

64063587
64063588
64063631
64063835
64063999
64064293
64064724
64064971
64066336
65019066

65019667
65023174
65025047
65026126
65027231
65027416
65027707
65027708
65028116
65060409
65060483
65060652
65060684
65060737
65060796
65061226
65061567
65061895
65061896
65062346
65062359
65052399
65062483
65062485
65062489
65062504
65062507
65062543
65062572
65062300

AS OF $07 / 03 / 69$

65062804
65062892
65062911
65062999
65063172
65065046
65065193
65065405
65065794
65065815

65065818

66010930

66011644

66012619

66014644

66014929

66018084

66019184

66021082

66021087

66021669

5607.1679

66021680

66021689

66021695

66022509

66022988

66.023067

66024150

66025530

66025986

66026120

66026122

66026123

66026124

6602612.5

$\$ 6026126$

66026598

66.026550

66027410

66027435

66027693

66027694

66028204

66028433

66028462

66028495

66028687

66028958

66030146

$\begin{array}{ll}66030342 & 66062972 \\ 66030452 & 66063702 \\ 66030453 & 66063756 \\ 66030644 & 66063781 \\ 66060155 & 66063923 \\ 66060267 & 66063926 \\ 66060594 & 66063931 \\ 66060596 & 66064123 \\ 66060600 & 66064334 \\ 66060637 & 66064456\end{array}$

66064513

66064619

66064688

66064722

66065118

66065264

66065371

66065445

66065501

66065709

66065767

66065770

67010007

67010038

6701.0310

67010836

67011394

67011597

67011971

67012048

67012128

67012478

67012840

67013691

67014051

67014071

67014142

67014311

67014312

67014916

67015033

67015715

67016233

67016619

67016947

67017216

67017489

67017582

67017584

67017609

Fig. 5. Library of Congress Number Listing. 
Processing of MARC Tapes/BIERMAN and BLUE 49

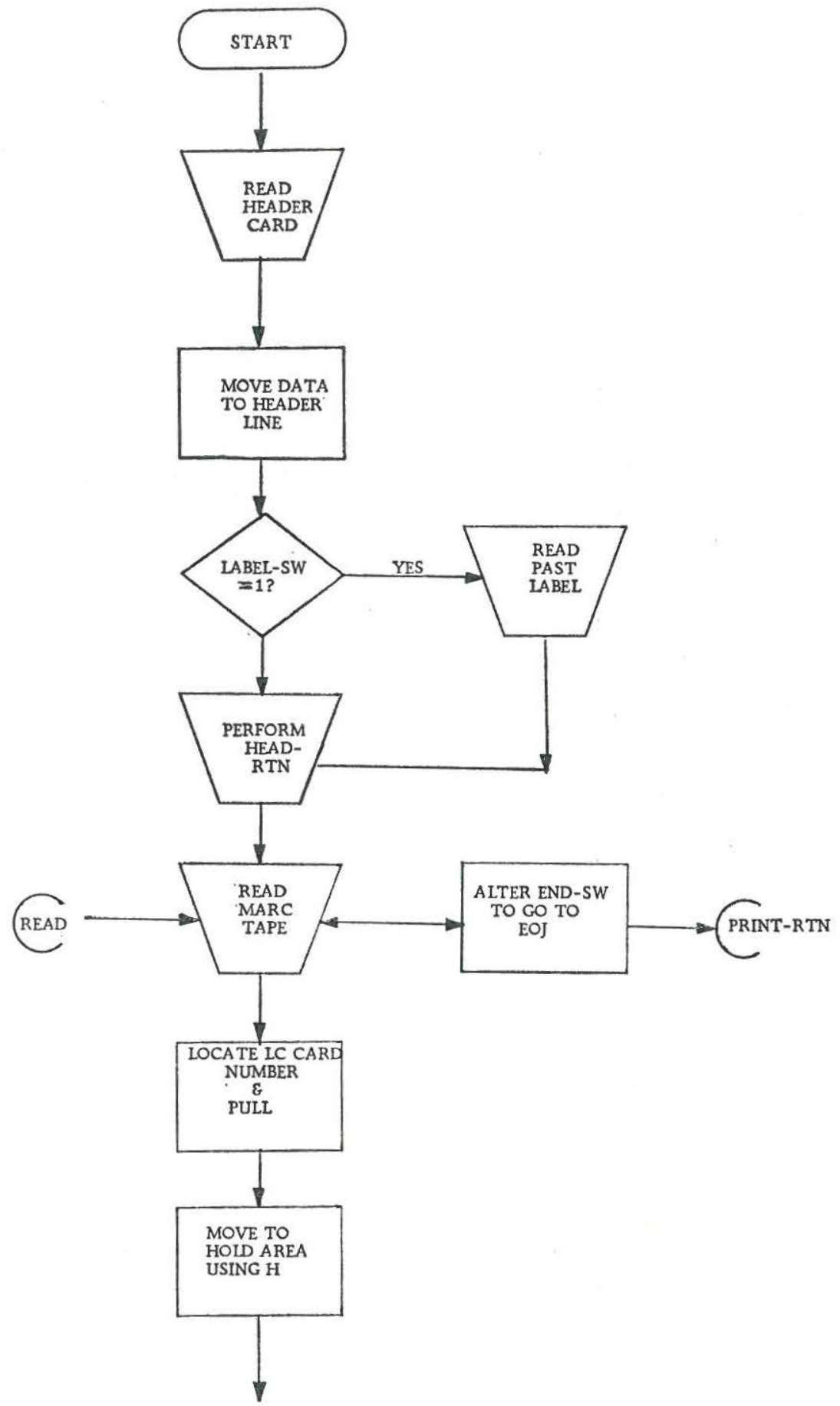

Fig. 6. Print Card Numbers Program Detail Flowchart. 
50 Journal of Library Automation Vol. 3/1 March, 1970

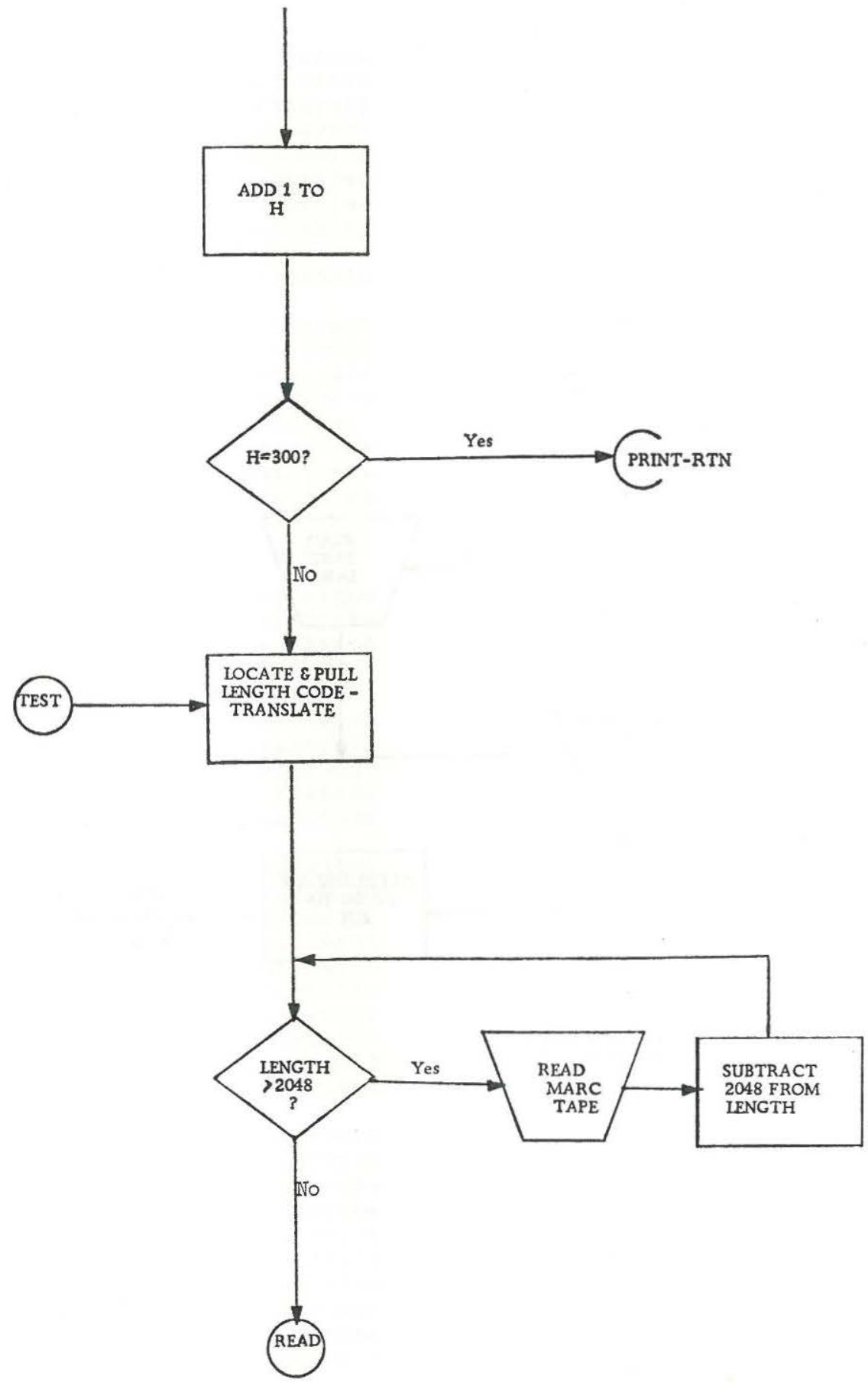

Fig. 6 continued. 

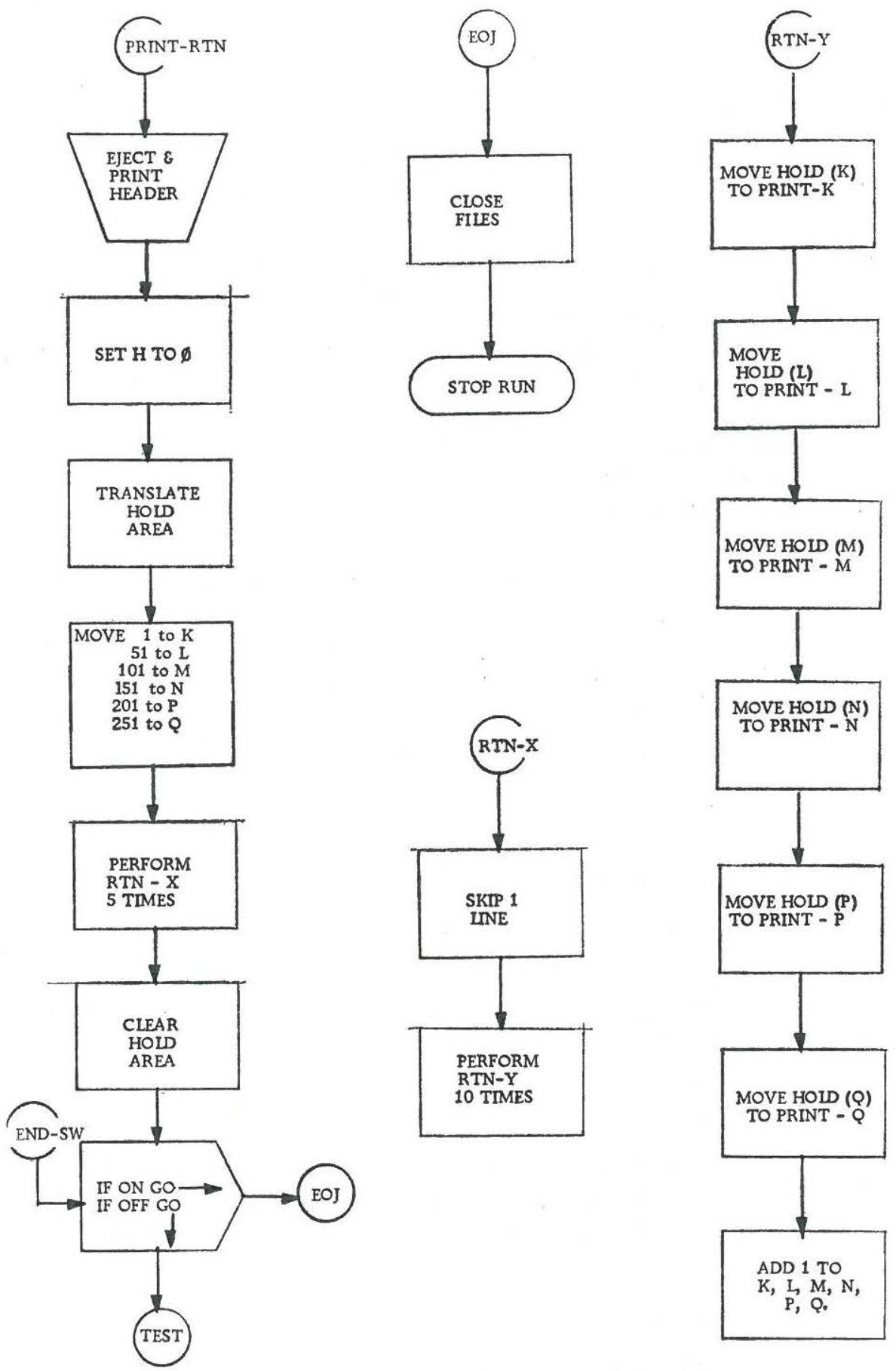

Fig. 6 continued. 


\section{RETRIEVAL SUB-SYSTEM}

\section{Withdrawing Records Program}

This program withdraws records selected by LC card number and copies the complete MARC II records onto another tape. A library sends the Department of Libraries a magnetic tape containing the LC card numbers for the records it wants copied from the data base. The data base is searched and the requesting library is sent back three tapes and three hard copies. The tapes are: 1) the original finder tape, 2) an item tape containing the records which matched, and 3) a tape containing the LC card numbers of the records which did not match. The three hard copies are: 1) a list in LC card number order of the records which matched containing on the first line information from the finder tape and on the second line information from the MARC tape; 2) a listing of the card numbers and other information on the finder tape which did not match any card number in the data base; 3) a listing of card numbers and other information on the finder tape that were invalid.

There are three inputs to the system, the first being a MARC master, which is the latest merged master at the Department of Libraries; its records are in the original code and format. The second consists of finder records, which come from the individual library. Input is originally on card in the format specified in Table 1 , then put on tape, blocked 5, and sorted (no tape labels are used at this time) on all 12 positions of the LC number. The tapes are unlabeled upper-case EBCDIC 1600 BPI. The third is a card that enters the appropriate date and library code into the system.

\section{Table 1. Original Card Input Format To ODL- $\$ 5$}

\section{Card Columns Field Contents and Special Instructions}

1

$2-4$

$5-12$

13

$14-28$

$29-48$

$49-76$

$77-80$
Local Library Code (assigned by Dept. of Libraries)

LC card number prefix (upper case alpha or blank)

LC card number (numeric)

LC card Supplement Indicator (may be blank)

Local Use (may be blank)

Local Use or first 20 positions of Author (may be blank) Local Use or first 28 positions of Title (may be blank) Local Use or Publication Date (may be blank)

The system gives the following five outputs:

1) Matched records, a listing of records that matched and were transferred to the individual library's item tape. This listing shows all informa- 


\section{Processing of MARC Tapes/BIERMAN and BLUE 53}

tion from the finder record, and immediately below, the following information from the MARC record: LC card number, the first 20 characters of the author, and first 28 characters of the title and the publication date. Information pulled is as follows: author (first tag beginning with 1 ), which will usually be 100 or 110 ; title, which will always be 245 ; and date, which will be the 7-10 positions under tag 008 . Figure 7 shows sample of output. The first line is data from the finder tape and the second line data from the MARC master tape.

\begin{tabular}{|c|c|c|c|c|c|}
\hline \multicolumn{2}{|c|}{ MATCHED RECORDS } & \multicolumn{2}{|c|}{ LIBRARY CODE $X$} & DATE PROCESSEO . $06 / 15 / 69$ & \multirow[b]{2}{*}{ DATE } \\
\hline & NUMBER & LOCAL USE & AUTHOR & TITLE & \\
\hline & 640663336 & & $\begin{array}{l}\text { ARCO PUBLISHING COMP } \\
\text { ARCO PUBLISHING, COMP }\end{array}$ & $\begin{array}{l}\text { OPERATIONS AND MAINTENANCE } \\
\text { OPERATIONS AND MAINTENANCE: } T\end{array}$ & $\begin{array}{l}1966 \\
1966\end{array}$ \\
\hline & 66021680 & & $\begin{array}{l}\text { KNOX, JOHN JAY } \\
\text { KNOX, JOHN JAY, } \$ 0182\end{array}$ & $\begin{array}{l}\text { A HISTORY OF BANKING IN THE } \\
\text { A HISTORY OF BANEING IN.THE }\end{array}$ & $\begin{array}{l}1969 \\
1969\end{array}$ \\
\hline & 67021200 & GIL/PIC & $\begin{array}{l}\text { GILBERT } \\
\text { GILBER.T, STEPHEN G.E }\end{array}$ & $\begin{array}{l}\text { PICTORIAL ANATOMY OF THE CAT } \\
\text { PICTORIAL ANATOMY OF THE CAT }\end{array}$ & $\begin{array}{l}1968 \\
1968\end{array}$ \\
\hline & 67023086 & & $\begin{array}{l}\text { DICKINSON, EMILY } \\
\text { DICKINSON, EMILY, SDI }\end{array}$ & $\begin{array}{l}\text { THO POEMS. } \\
\text { TWO POEMS -SC*ILLUS. AND CALL }\end{array}$ & $\begin{array}{l}1968 \\
1968\end{array}$ \\
\hline & 68008044 & & $\begin{array}{l}\text { GERNSHEIM, HELMUT } \\
\text { GERNSHEIM, HELMUT, \$O }\end{array}$ & $\begin{array}{l}\text { L. J. M. DAGUERRE } \\
\text { L. J. M. DAGUERRE*SBTHE HIST }\end{array}$ & $\begin{array}{l}1968 \\
1968\end{array}$ \\
\hline & 68008234 & & 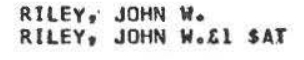 & $\begin{array}{l}\text { THE STUDENT LOOKS AT HIS TEA } \\
\text { THE STUDENT LOOKS AT HIS TEA }\end{array}$ & $\begin{array}{l}1969 \\
1969\end{array}$ \\
\hline & 68008418 & & $\begin{array}{l}\text { TAGIURL; RENATO } \\
\text { TAGIURI, RENATO.EI } \$\end{array}$ & $\begin{array}{l}\text { ORGANIZATIONAL CLIMATE } \\
\text { ORGANIZATIONAL CLIMATE \#\$BEXP }\end{array}$ & $\begin{array}{l}1968 \\
1968\end{array}$ \\
\hline & 68025737 & & BAZIN, GERMAIND $\varepsilon 1$ SA & $\begin{array}{l}\text { TWE BARQOUE PRINCIPLES, STY } \\
\text { THE BARCQUE* PRINCIPLES, STY }\end{array}$ & $\begin{array}{l}1968 \\
1968\end{array}$ \\
\hline & 69015554 & 36823 & $\begin{array}{l}\text { PHILIPS, JUDSON } \\
\text { PHILIPS, JUDSON PENT }\end{array}$ & $\begin{array}{l}\text { GIRE WITH SIX FINGERS } \\
\text { THE GIRL WIIH SIX FINGERS*\$B }\end{array}$ & $\begin{array}{l}1969 \\
1969\end{array}$ \\
\hline & 77002574 & & $\begin{array}{l}\text { AYLMER, G. E. } \\
\text { AYLMER, G. E.EI SATH }\end{array}$ & $\begin{array}{l}\text { THE STRUGGLE FOR THE CONSTIT } \\
\text { THE STRUGGLE FOR THE CONSTIT }\end{array}$ & $\begin{array}{l}1968 \\
.1968\end{array}$ \\
\hline & 78625296 & & $\begin{array}{l}\text { GROVES, DORIS } \\
\text { GROVES, DORIS.EI \$AG }\end{array}$ & $\begin{array}{l}\text { GUIDING THE DEVELOPMENT OF } \\
\text { GUIDING THE DEVELOPMENT OF T }\end{array}$ & $\begin{array}{l}1968 \\
1968\end{array}$ \\
\hline & 79000540 & & $\begin{array}{l}\text { AMERICAN ASSOCLATION } \\
\text { AMERICAN ASSOCIATION }\end{array}$ & $\begin{array}{l}\text { PREPARATION FOR RETIREMENT } \\
\text { PREPARATION FOR RETIREMENT*\$ }\end{array}$ & $\begin{array}{l}1968 \\
1968\end{array}$ \\
\hline$A C 6$ & 68004152 & & $\begin{array}{l}\text { WELLS, ROBERT } \\
\text { MELLS; ROBERT, SD1913 }\end{array}$ & $\begin{array}{l}\text { SC IENCE-HOBBY BOOK OF WEATHE } \\
\text { SCIENCE }=\text { HOBBY BOOK OF WEATHE }\end{array}$ & $\begin{array}{l}1968 \\
1968\end{array}$ \\
\hline AGR6 & 68000145 & & $\begin{array}{l}\text { SANTMYER, CAROLEE } \\
\text { SANTMYER; CAROLEE, SD }\end{array}$ & $\begin{array}{l}\text { MDROCCO S AGRICULTURAL ECONO } \\
\text { MOROCCO S AGRICULTURAL ECONO }\end{array}$ & $\begin{array}{l}1968 \\
1968\end{array}$ \\
\hline GS 6 & 68000236 & & $\begin{array}{l}\text { US GEOLOGICAL SURVEY } \\
\text { MEATH, JO ANN, \$DI923 }\end{array}$ & $\begin{array}{l}\text { BI RLIOGRAPHY OF REPORTS RESU } \\
\text { BIBLIOGRAPHY OF REPORTS RESU }\end{array}$ & $\begin{array}{l}1968 \\
1968\end{array}$ \\
\hline & & AUVD V & $\begin{array}{l}\text { ICS } \\
\text { IRS }\end{array}$ & & \\
\hline
\end{tabular}

Fig. 7. Matched Records Listing. 
2) Items tape, containing all records requested from the master tape. They are in MARC format and code, and the number of logical records should match the matched record count.

3) Unmatched finders listing, showing all valid finder records that did not match the MARC master tape. Figure 8 shows sample output.

4) Unmatched finders tape, containing all valid finder records that did not match the MARC master tape.

\begin{tabular}{lll}
$\begin{array}{c}\text { UNHATCHEO RECORUS } \\
\text { LC NUMBER }\end{array}$ & \multicolumn{1}{c}{ LIERARY CODE $X$} \\
39015412 & PADAL USE & \multicolumn{1}{c}{ AUTHOR } \\
60007163 & 3468 & PADELFORO \\
640635 A & & BELLI, MELVIN \\
68002763 & & CASWELL, BARBARA W \\
68055404 & & BELLI \\
68066507 & & EISEMAN, ALBERTA \\
70003466 & & ROBECK, MILCREO \\
71079310 & & \\
HEW68000053 & PIVENH/EDUC &
\end{tabular}

Fig. 8. Unmatched Records Listing.

\begin{tabular}{lc}
\multicolumn{1}{c}{ DATE PROCESSED } \\
TITLE & $06 / 15 / 69$ \\
IVTERNATIONAL LAW & 1939 \\
BELLI LCOKS AT LIFE & 1960 \\
WORKMENS COMPENSATION HENEF I & 1963 \\
LAW REVOLT & 1968 \\
THE GUEST DOG & \\
SPECIAL CLASS PRUGRAMS FOR & 1968 \\
THE FXIENOED CARE FACILITY & 1967 \\
THE MEOITFRRANEAN, TTS ROLF & 1969
\end{tabular}

TITAL UNMATCHEO RCDS 9

\begin{tabular}{|c|c|c|c|c|c|}
\hline \multicolumn{2}{|c|}{ ERROR LISTING } & LIBRARY CODE $X$ & \multicolumn{2}{|l|}{ DATE PROCESSED } & \multirow[b]{2}{*}{ INVALIC LC = NUMBER } \\
\hline$x$ & 66016065 & $\mathrm{RICH}$ & NECESSITIES OF LIFE & 1966 & \\
\hline$x$ & 68055404 EISEGUEST & & & & DUPLICATE LC NUMBER \\
\hline$x$ & $73 A 43622$ & BLEINHEIM & THE RISE AND FALL OF THE & 1970 & INVALIC LC= NUMBER \\
\hline J & 95000001 & & & & INVALIO LIBRARY CODE \\
\hline J69 & 680000384683986 & & & & INVALIO LIBRARY CODE \\
\hline JG9 & 680000384683986 & & & & INVALIO LC = PREFIX \\
\hline JHEW & W73697836 HEISBLUE & & & & INVALID LIBRARY CODE \\
\hline XHE 3 & $3 A 3326092$ & & & & INVALIO LC $=$ PREFIX \\
\hline XHE 3 & $3 A 3326092$ & & & & INVALIO LC $=$ NUMBER \\
\hline $\mathrm{XH} 3 \mathrm{~W}$ & W79000366 & JONES & RELATLONSHIPS AMCNG & 1969 & INVALIC LC = PREFIX \\
\hline J326 & 668000069 & CURTIS & THE MAKING OF A PRESIOENT & 1969 & INVALIO LIBRARY CODE \\
\hline 3326 & 668000069 & CURTIS & THE MAKING OF A PRESIDENT & 1960 & INVALIO LC = PREFIX \\
\hline J326 & 668000069 & CURTIS & THE MAKING OF A PRESIDENT & 1969 & INVALIO LC $=$ NUMBER \\
\hline \multirow{2}{*}{\multicolumn{2}{|c|}{$\times 32669005736$ HEW3265H132 }} & & & & INVALIC LC $=$ PREFIX \\
\hline & & & & \multicolumn{2}{|c|}{ TOTAL FRRORS = } \\
\hline
\end{tabular}

Fig. 9. Errors Listing. 
5) Errors listing, showing all 80 columns of invalid finder records and the appropriate error message. Finder records are invalid if one of the following errors occurs: 1) blank or invalid library code; 2) prefix any characters except blank or upper-case alpha; 3) LC card number not pure numeric. Invalid finder records are not processed but are placed on an error listing. Figure 9 shows sample output. No edits will be made on columns 14-80, which are for local use entirely; all data from these fields will be transmitted to printed listings for any desired local use or for verification.

Record counts are included at numerous points to facilitate accurate record control. For the purposes of this particular program, counts should check as follows:

$$
\underset{\text { Records }}{\text { Matched }}+\text { Errors }+\underset{\text { Records }}{\text { Unmatched }}-\underset{\text { Errors }}{\text { Generated }}=\underset{\text { Count }}{\text { Original }}
$$

Matched records appear at the end of the listing of the same name, errors appear at the end of the listing of the same name, and unmatched records appear at the end of the listing of the same name. Generated errors appear at the end of the matched records listing. A generated error indicates more than one error in a single card and this count is included only for control purposes. The original count is expected to be maintained by the submitting library for maximum accuracy. These counts are checked immediately, and any discrepancies cleared up as soon as possible.

Figure 10 gives the overall view of the program and Figure 11 a detailed flowchart.

The ODL- 95 program was written to provide the greatest flexibility possible to the user libraries. The only information absolutely required for the finder tape is the local library code, and the complete LC card number. However, the remaining 67 card columns are available to the local library for any use it may wish to make of them. If the local library would like a quick method of sight checking to make sure that the records copied were the records wanted, it can keypunch the first twenty characters of the author in columns 29-48, the first 28 characters of the title in columns 49-76, and the date of publication in columns 77-80. If this is done, the matched records listing will contain the author, title and date from the finder tape, immediately followed underneath in the same position on the page by the corresponding information from the MARC record. Figure 7 shows sample output. Thus, the library can quickly sight check what it thought it was getting at the time of request with what it actually got from the MARC record. Of course, the local library is free to put no information, or other information, in columns 29-80; the operation of the system will not be affected and whatever information is included in columns 29-80 will appear on the three output listings (matched records, unmatched finders and errors). 
56 Journal of Library Automation Vol. 3/1 March, 1970

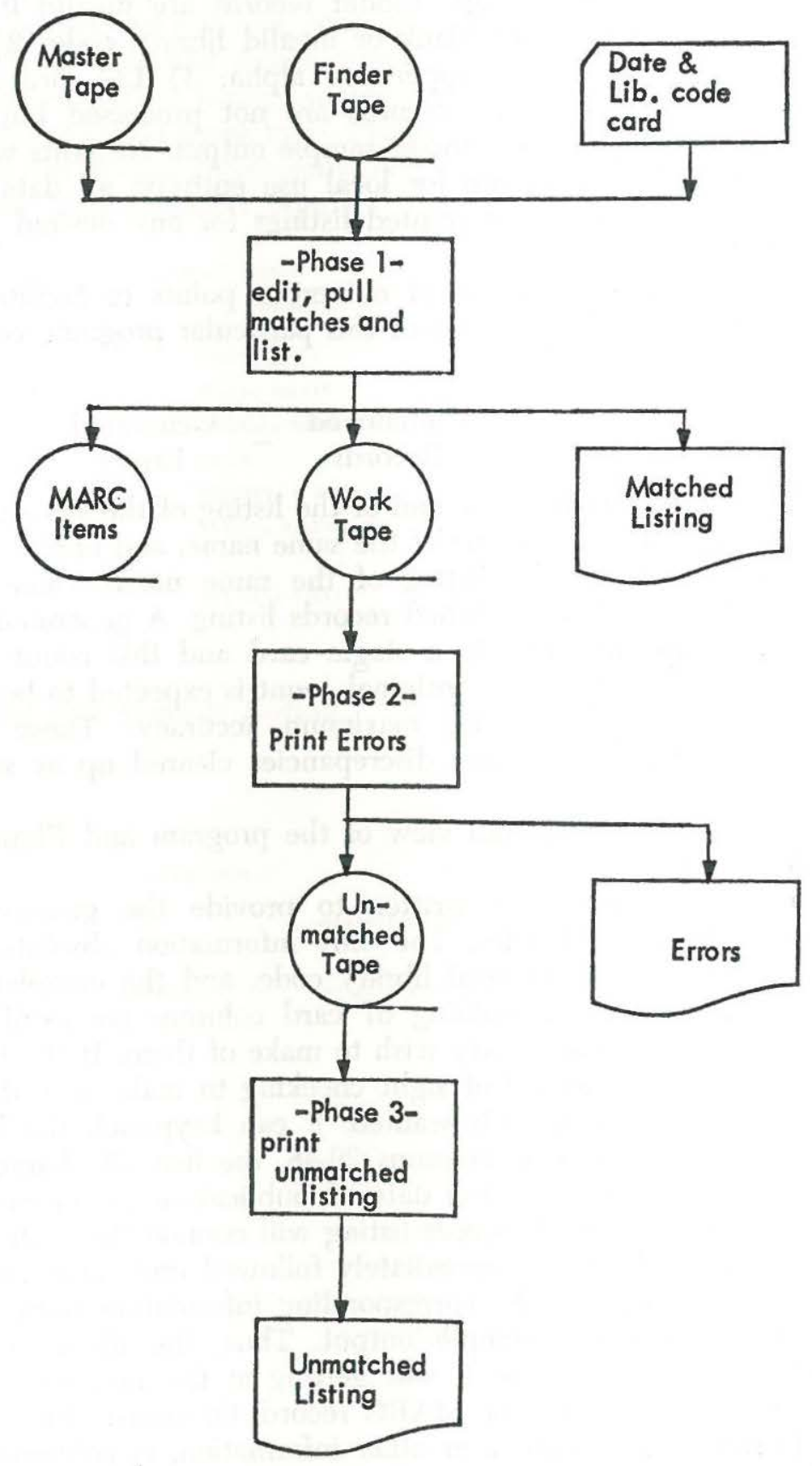

Fig. 10. Withdrawing Records Program System Flowchart. 


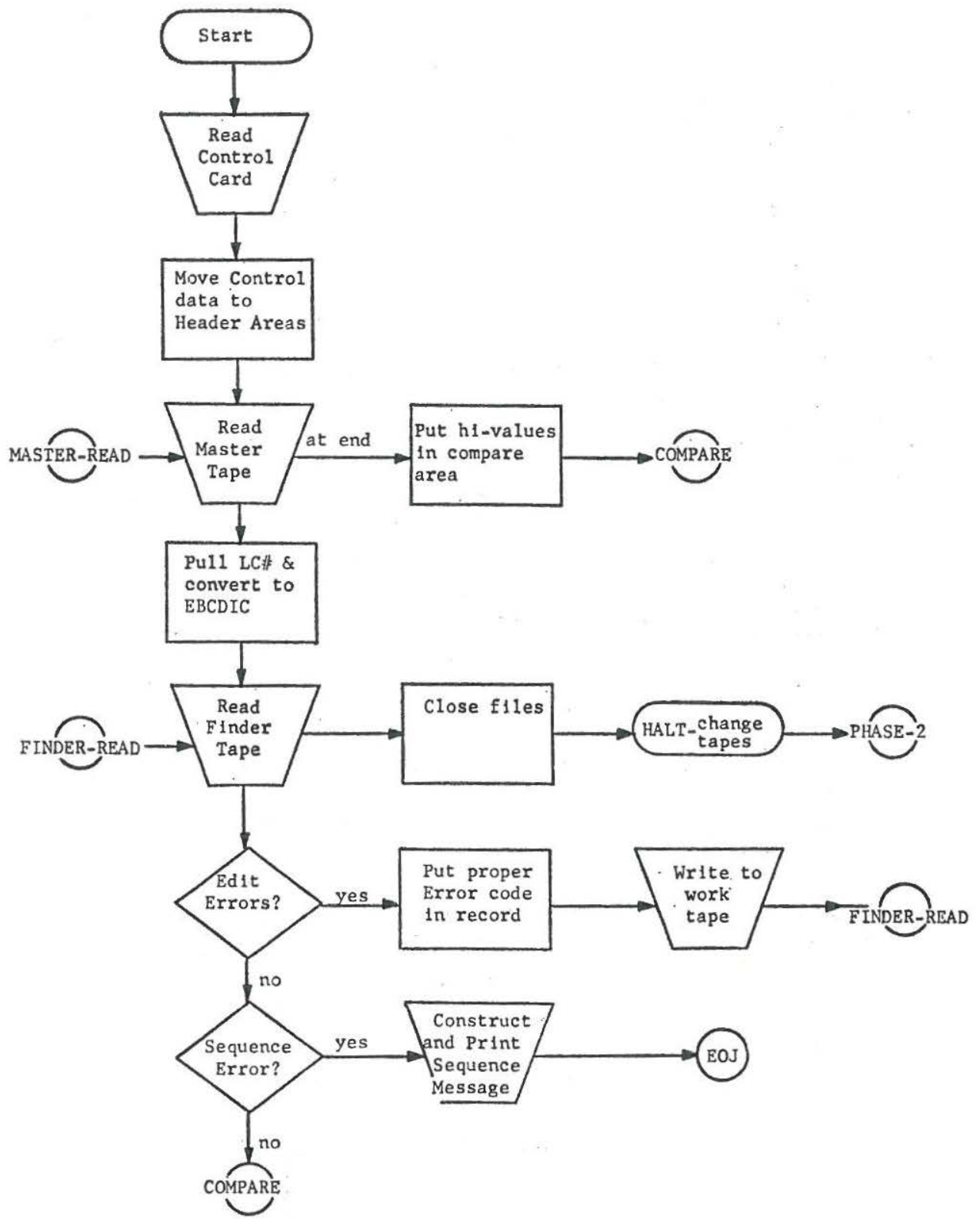

Fig. 11. Withdrawing Records Program Detail Flowchart. 
58 Journal of Library Automation Vol. 3/1 March, 1970

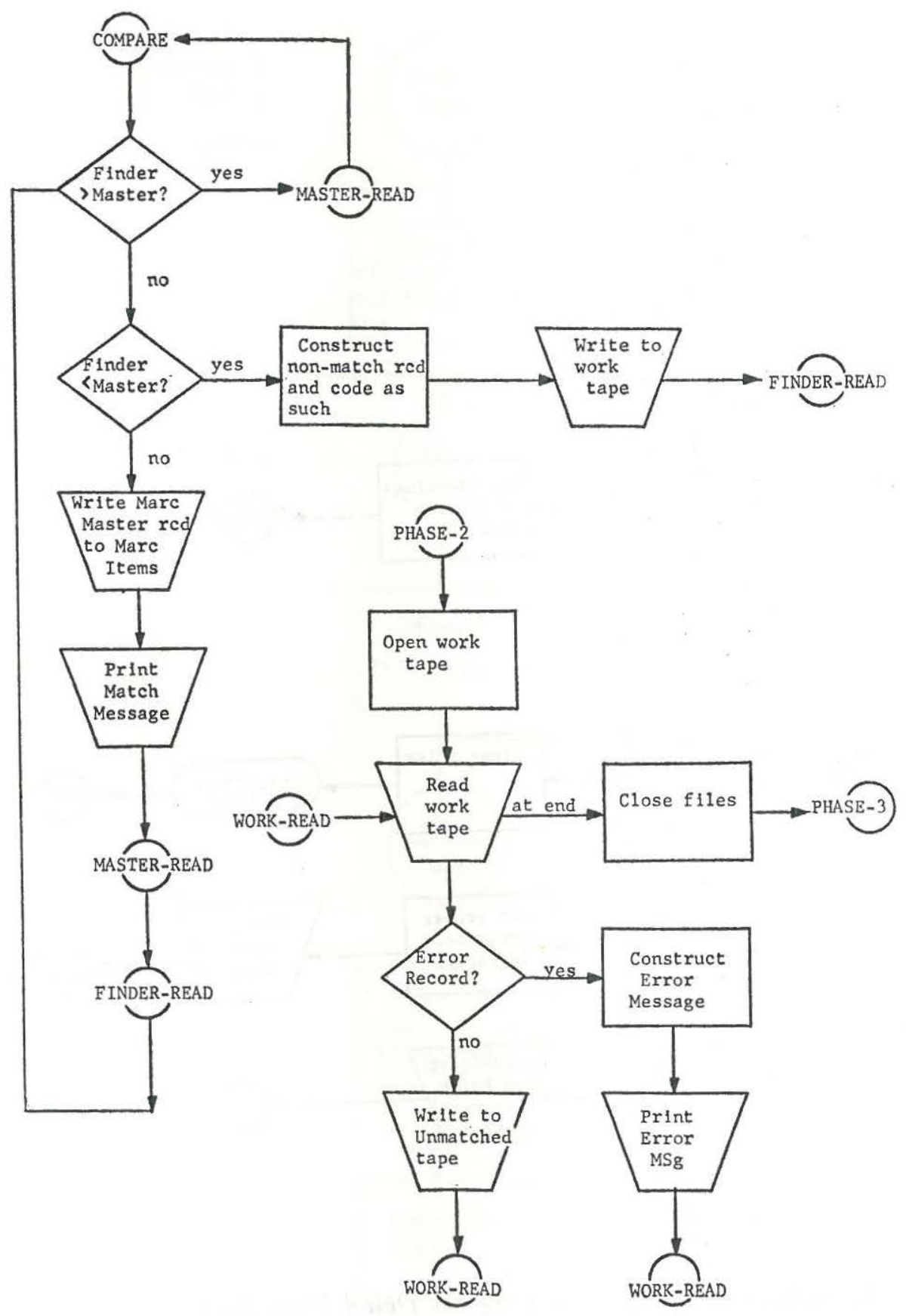

Fig. 11 continued. 

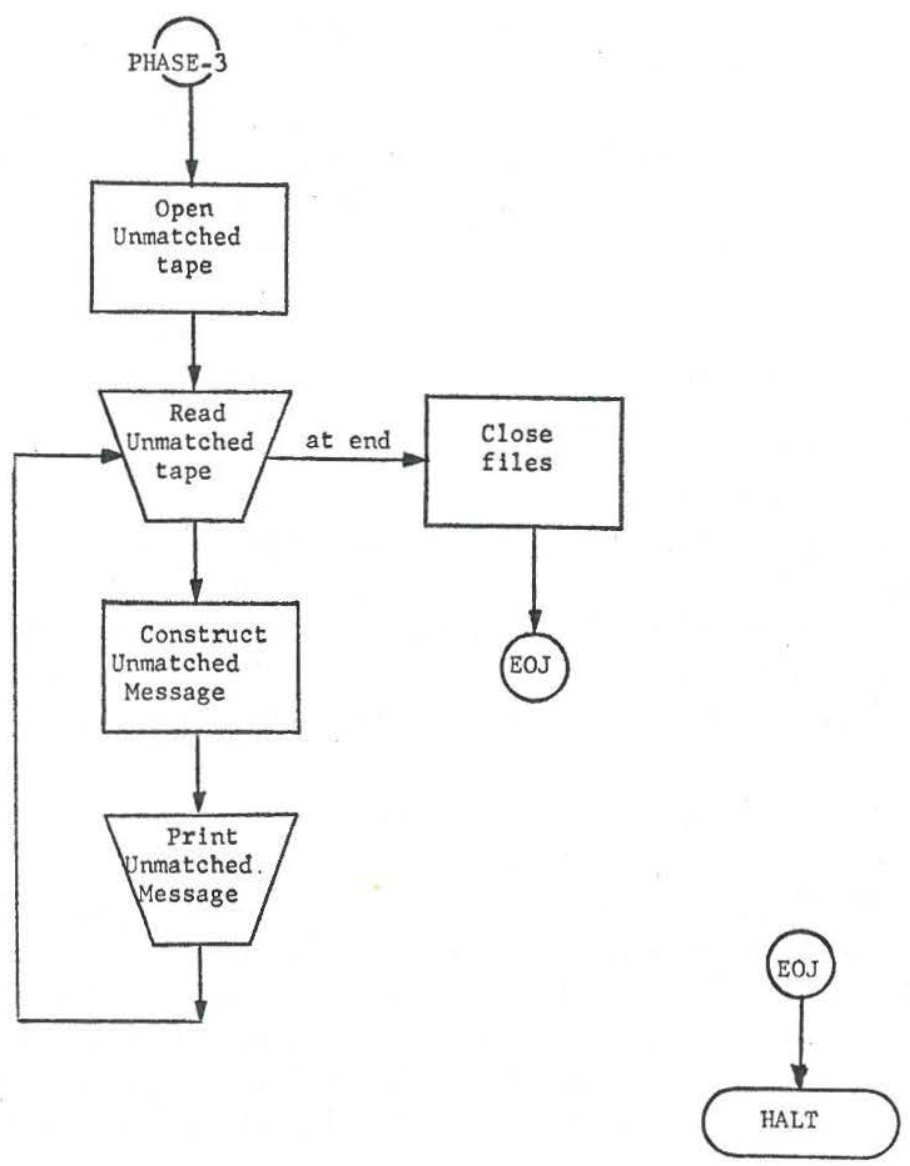

Fig. 11 continued.

Another convenience for the local library is that it has to do no original programming to use the system. All that is needed are standard sort, merge and card-to-tape programs. Any of the programs written by the Department of Libraries is available to users on demand. They may find the merge or LC card number print programs useful.

Another consideration for the user is the ease with which invalid finder records and unmatched finder records can be resubmitted into the system. To correct finder records in error, the library simply repunches cards from the error listing, with necessary corrections, and resubmits them in the next cycle with new cards. Unmatched finder records can be merged with any new finder records in the next cycle and resubmitted, no repunching being necessary. 


\section{WHAT IS PRESENTLY BEING DONE}

The variety of applications for MARC presently being worked on in Oklahoma libraries is most interesting. Central State College, Edmond, Oklahoma, is currently subscribing to the weekly MARC tapes and producing an index of available materials which cumulates for two months and then drops off the older entries. The library is receiving its own subscription to the MARC tapes for this purpose but does not plan to maintain a complete file of MARC records.

The Tulsa City-County Library System, Tulsa, Oklahoma, is currently using MARC records from the State data base for bibliographic information for its machine produced book catalog. It originally had a subscription to the MARC tape service, but with the operation of the state-wide data base, is dropping it.

The University of Oklahoma, Oklahoma State University, and Oklahoma County Libraries have no immediate plans for utilization of the MARC records as distributed by the Library of Congress; however, when they do move in this area it will probably be for use in their technical processing departments and the State MARC Data Base will form a basis for their use.

\section{COMPUTER AND LANGUAGE USED}

The computer being used for the Department of Libraries MARC program is an IBM $360 / 30$ located in the State Budget Bureau but under the administrative control and operation of the Information and Management Services Division of the Board of Affairs (the centralized state computer center for the Capitol complex). The computer has $32 \mathrm{~K}$ core size, one on-line card read/punch, Model 2540, four magnetic tape drives, Model 2415, two magnetic disk drives, Model 2311, and one on-line printer Model 1404.

The programs are written in COBOL for the $360 / 30$, operating under DOS, with a COBOL compiler. Very little modification would be required to operate under OS. The merge program (ODL- $\emptyset 1$ ) requires three tape drives. The withdrawing program (ODL- $\emptyset 5$ ) requires four tape drives but could be modified to operate with only three tape drives. In agreement with Henriette Avram and Julius Droz (4), the Department of Libraries has found that COBOL can easily be used to process MARC records.

The Information and Management Services Division has assigned a programmer to the Department of Libraries who has done, and will do, all the MARC programming. She is actually employed by the IMSD and the Department of Libraries contracts with them for her services. Presently, the Department is being charged about $\$ 7.00$ an hour for programming time. The planning, system design, actual programming, and production are all closely supervised by the Data Processing Coordinator of the Library, and he is on the Department of Libraries' staff. 
The relationship between the IMSD and the ODL has been extremely beneficial for the Library. Thus far, the centralized computer center has provided fast and excellent service at a minimum cost. Having a fulltime data processing coordinator on the staff of the library has negated the communication barrier which so often exists between a computer service center and a user library.

\section{COST}

Cost figures for use of MARC are very difficult to find. Few of the MARC I participants (3) give anything but a fleeting reference to cost. The reason is clear: cost figures are difficult to determine and even more difficult to evaluate meaningfully. Table 2 is a breakdown of the charges to the Department of Libraries for programming and machine time; it does not include Department of Libraries' staff time or overhead costs. The figures are accurate through the end of February 1970.

Table 2. Costs

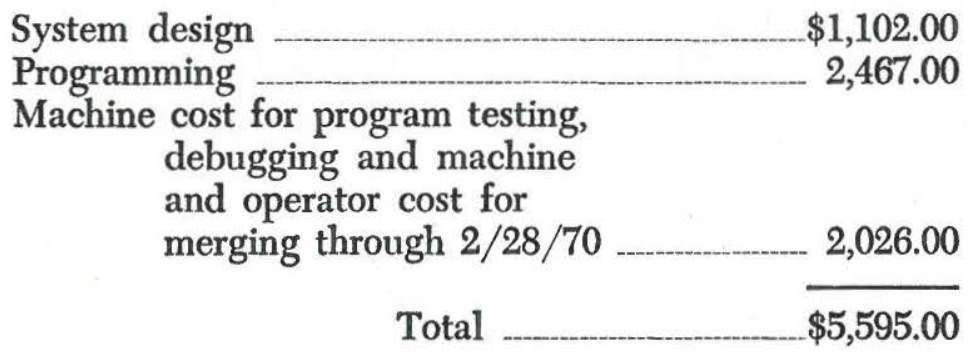

For the first year, the Department of Libraries is absorbing all the costs of merging and maintaining the MARC master file, as well as the costs of all programming, as a form of state aid to libraries. The machine costs of comparing a finder tape with the master file, copying the desired records, and printing the various hard-copy lists, is being absorbed by the user library. The user also supplies the two blank tapes which are needed for each run. The machine time costs are based on the rate of $\$ 80.00$ an hour of CPU time.

\section{PLANS FOR THE FUTURE OF THE STATE-WIDE MARC MASTER FILE}

Two major problems are apparent in the system as it is now set up. The system was initially created as a sequential tape system because this was the easiest and quickest way to establish a working system, and because it was felt that this would be practical for at least the first year of operation. One problem is that the sequential file will become expensive to maintain and does not allow direct access to a particular record without a sequential search. Another problem is that the present system allows entry into the file only by LC card number and does not allow entry directly with bibliographic information. 
In accordance with present plans, in March 1970 work will begin on converting the storage medium from tape to a direct access device (disk or data cell) as the RECON Study suggests (5). At that time the file will cease to be maintained in LC card number order and will be maintained in the order in which the records are received from the Library of Congress. Various indices to the MARC data base will be produced; author and title indices will enable the data base to be searched by bibliographic information when the LC card number is not known. In this way, only the indices (which would be comparatively much smaller), and not the complete data base, would have to be merged and searched. In terms of the data base itself, this will be the next major change.

In the long run, it will be desirable for libraries that want access to the MARC data base to have such access directly via terminals. At the present time, the cost of this kind of access is not worth the increased speed of access, nor is the money presently available; however, in the future, the cost of such a system will surely be reduced by technological improvements and increased importance of instantaneous access to the data base. When need balances with cost, such a set-up will be feasible.

The geographical expansion of the system is a possibility. Economically, this is most desirable, because the more ways the cost of maintaining the data base is split, the cheaper it is for all involved. Some preliminary investigation along these lines with bordering states is being made and hopefully at some time in the future there will be a regional data base which many libraries can use.

\section{PLANS FOR FUTURE COOPERATIVE USE OF MARC}

The cooperative use of MARC thus far in Oklahoma only affects the larger libraries which have access to computers and automation personnel. Essentially, each library is autonomous and is free to use MARC in any manner it wishes. It will remain true in Oklahoma that individual libraries will always be free to use the data base to retrieve part or all of the data base for any purpose. However, plans are under way for more cooperative use of MARC with libraries that do not have automation capabilities that would result in useful hard copy products for such libraries.

Two such cooperative plans have been proposed for immediate implementation. The first of these is a current awareness service. Selected subjects would be compared against the data base on a bi-weekly (or other period) basis and complete bibliographic information for books representing the selected subjects would be printed as a personalized current awareness service. For example, all law titles on the MARC tapes for two weeks could be pulled and listed, and the listing distributed to the county and state law offices, attorney firms, the Law School Library, etc., for selection and order purposes. The same could be done with library 
science or any other subject. Subject lists of interest to various agencies of state government could be produced and sent to them. Another possibility is a profile of a legislative session by subject and then weekly or monthly lists of current materials available on these subjects for ordering by the Department of Libraries and possible lists to be made available to the legislative members. There are many possible uses for such a system which could be done fairly inexpensively. Work began on this project in October 1969, and the service became operational on a cost basis in February 1970.

A second possibility is catalog card and processing aids production. This would probably be done as a pilot project with several libraries throughout the state and then, if successful, expanded to any library in the state wanting to use the service. Catalog card sets with subject headings printed at the top, and call numbers printed if the library accepts LC or LC Dewey classification (there would be several options available within the system), spine labels, and book and circulation card labels would be provided. A by-product of such a state-wide operation would be the maintenance of book location information in machine readable form in a central place for future use as a basis for a machine readable state-wide union catalog.

A project not in the immediate future but certainly being considered is that of cooperative retrospective conversion. That is, several libraries in the State would like to have bibliographic information in MARC format for all books in their collections. Whether the Department of Libraries would go ahead with such an ambitious project or wait for it to be done nationally (RECON Study) would depend on timeliness on the national scene, need on the local scene, and available financial resources. Eventually, Oklahoma would like to have in machine readable form a complete union catalog of the entire library resources of the State that could be used for cooperative acquisitions programs, for strengthening subjects which are weak within the State, and as a location tool for interlibrary loan. Such a data base would later be used also for reference functions. Needless to say, such an ambitious project as this is not in the immediate future.

\section{CONCLUSION}

Early in the game, Oklahoma libraries learned that the most economical means to library automation was cooperative automation. The creation of a state-wide MARC data base is an important step toward cooperative library automation, while still allowing each local library to maintain its individuality for uses of the data. Many areas of cooperation still remain untouched. The future success of library automation in Oklahoma lies in the imaginative and creative projects that could be designed and implemented cooperatively to the mutual cost savings and benefit of all. 


\section{PROGRAMS}

Copies of the programs mentioned in this paper may be obtained from National Auxiliary Publications Service of ASIS as follows: 1) "A Program to Merge All MARC II Tapes Received from the Library of Congress onto a Single Tape" (NAPS 00815); 2) "A Program to Drop Given Records or to Transfer Them to a Separate Tape" (NAPS 00816); 3) "A Program to Print MARC Tapes in Readable Form" (NAPS 00817); 4) "A Program to Pull Selected Records from the MARC Master Tape for a Single Library" (NAPS 00818); and 5) "A Program to Print a Listing of All Library of Congress Card Numbers on a Given MARC Tape" (NAPS 00819).

\section{REFERENCES}

1. Nugent, William R.: "NELINET: The New England Library Information Network." A paper presented at the International Federation for Information Processing, IFIP Congress 68, Edinburgh, Scotland, August 6, 1968. (Cambridge, Mass.: Inforonics, Inc., 1968), 4 pp.

2. Pulsifer, Josephine S.: "Washington State Library." In Avram, Henriette D.: The MARC Pilot Project; Final Report on a Project Sponsored by the Council on Library Resources, Inc. (Washington: Library of Congress, 1968), pp. 149-165.

3. Avram, Henriette D.: The MARC Pilot Project; Final Report on a Project Sponsored by the Council on Library Resources, Inc. (Washington: Library of Congress, 1968), pp. 89-183.

4. Avram, Henriette D.: Droz, Julius R.: "MARC II and COBOL," Journal of Library Automation, 1 (December 1968), 261-72.

5. RECON Working Task Force: Conversion of Retrospective Catalog Records to Machine-Readable Form; A Study of the Feasibility of a National Bibliographic Service. (Washington, D. C.: Library of Congress, 1969). 